\title{
Multitemporal analysis of the NDVI Distribution in the city of Garanhuns-PE
}

This research aimed to analyze the effects of urbanization on the distribution of the NDVI in the urban area of the municipality of Garanhuns, in the state of Pernambuco. The referred region is going through a period of maximization of its urban perimeter, causing profound changes to the local landscape. The constant removal of vegetation cover created risk areas by intensifying surface runoff, while urban sprawl fueled by the lack of adequate urban planning allowed the occupation of improper areas such as natural slopes and the adjacencies of natural springs. Initially a topographic mapping of the study area was carried out, resulting in a digital elevation model and a watershed map. Subsequently, a multitemporal mapping of the NDVI was carried out using data from the Landsat 5 and 8 satellites. Through the results, it was possible to verify that the constant growth of the urban area created several imbalances in the natural landscape, especially in the vegetation cover. It was observed that even though the average NDVI has remained relatively constant over time, the standard deviation has the natural landscape, especially in the vegetation cover. It was observed that even though the average NDVI has remained relatively constant over time, the standard deviation has
changed sharply, suggesting disturbances in the NDVI distribution. This phenomenon is a product of Garanhuns' urban drainage, which consists of creating areas of high concentration of surface runoff directed at the natural slopes. It was found that the expansion of the urban area occurs around the aforementioned slopes and that the drainage system is implemented in such a way that all of the surface runoff is aimed at the slopes, creating a scenario where there are several impermeable areas and others with dense vegetation due to the abundance of water. Moreover, it was observed that the deficiencies in the region's urban planning created a scenario of environmental risk by increasing surface runoff in risk areas, thus intensifying erosive processes, which may cause mass movements such as landslides.

Keywords: Vegetation cover; Geomorphology; Surface runoff; Urbanization.

\section{Análise multitemporal da distribuição do NDVI na cidade de Garanhuns-PE}

A presente pesquisa teve como objetivo analisar os efeitos da urbanização na distribuição do NDVI na área urbana do município de Garanhuns, localizado no estado de Pernambuco. A referida região passa por um período de maximização do seu perímetro urbano, acarretando profundas modificações na paisagem local. A constante remoção da cobertura vegetal criou áreas de risco ao intensificar o escoamento superficial, enquanto que o crescimento desordenado impulsionado pela ausência de um planejamento urbano adequado propiciou a ocupação de áreas impróprias como encostas e as adjacências de nascentes. Inicialmente, foi realizado um mapeamento topográfico que resultou em um modelado do relevo e da dinâmica hídrica. Posteriormente, a partir de dados dos satélites Landsat 5 e 8 (anos 1990, 1995, 2000, 2004, 2009, 2015 e 2018) foi realizado um mapeamento multitemporal do NDVI. A partir dos resultados, foi possivel constatar que o crescimento desordenado gerou desequilibrios na paisagem natural, especialmente na cobertura vegetal. Foi observado que embora o NDVI médio 作 vertentes e o sistema de drenagem é implementado de tal maneira que todo o fluxo é direcionado às encostas, criando um cenário onde existem grandes áreas impermeáveis e outras com vegetação densa em virtude da abundância de fluxo. Ademais, foi possível observar as deficiências no planejamento urbano da região, que criou um cenário de risco geoambiental ao permitir a intensificação do fluxo superficial em áreas de risco que consequentemente intensificam os processos erosivos podendo acarretar movimentos de massa como deslizamentos de terra.

Palavras-Chave: Cobertura vegetal; Geomorfologia; Escoamento superficial; Urbanização.

Topic: Tecnologia, Modelagem e Geoprocessamento

Reviewed anonymously in the process of blind peer
Received: $27 / 04 / 2021$

Approved: 28/05/2021
João Vitor de Almeida Bezerra (D)

Universidade Federal Rural de Pernambuco, Brasil http://lattes.cnpq.br/0577287275286569 http://orcid.org/0000-0001-8767-4646 j.vitor.almeida@outlook.com

Edyellison Almeida Ramos (iD

Faculdades Integradas de Garanhuns, Brasil http://lattes.cnpq.br/8527989079956136 http://orcid.org/0000-0001-7424-660X edyalmeida.arq@outlook.com

\section{Lucas de Lucena Rocha}

Universidade Federal Rural de Pernambuco, Brasil http://lattes.cnpq.br/3728121678760017 http://orcid.org/0000-0001-7600-8293 lucasdelucenarocha@gmail.com
Tamara de Lima Oliveira (1D)

Faculdades Integradas de Garanhuns, Brasil http://lattes.cnpq.br/4162515876634749 http://orcid.org/0000-0001-5124-3772 tamaara oliveira@hotmail.com

\section{Felippe Pessoa de Melo (iD)}

Centro Universitário UniAGES, Brasil http://lattes.cnpq.br/9232465770550351 http://orcid.org/0000-0001-5363-016X felippemelo@hotmail.com

Ricardo Brauer Vigoderis (iD

Universidade Federal Rural de Pernambuco, Brasil http://lattes.cnpq.br/8447376601980922 http://orcid.org/0000-0001-8775-972X vigoderis@hotmail.com
Werônica Meira de Souza (iD)

Universidade Federal Rural de Pernambuco, Brasi http://lattes.cnpq.br/9039652038717693 http://orcid.org/0000-0002-6270-2345 weronicameira@gmail.com

\section{Cristiane Guiselini (iD)}

Universidade Federal Rural de Pernambuco, Brasil http://lattes.cnpq.br/4309083918019766 http://orcid.org/0000-0003-2909-9502 cristiane.guiselini@ufrpe.br

\section{Referencing this:}

BEZERRA, J. V. A.; RAMOS, E. A.; ROCHA, L. L.; OLIVEIRA, T. L.; MELO, F. P.; VIGODERIS, R. B.; SOUZA, W. M.; GUISELINI, C.. Multitemporal analysis of the NDVI Distribution in the city of Garanhuns-PE. Revista Ibero Americana de Ciências Ambientais, v.12, n.5, p.725-733, 2021. DOI: http://doi.org/10.6008/CBPC2179-6858.2021.005.0056 


\section{INTRODUCTION}

Anthropic actions can cause imbalances in the natural landscape, altering ecosystems and creating several negative environmental impacts that will eventually be felt by the population regardless of social status. According to Miguez et al. (2017) urbanization greatly changes the natural environment and the consequent expansion of the urban perimeter increases land consumption and infrastructure demands, with consequent built and natural environments degradation.

Disordered occupation is one of the biggest urban problems experienced by contemporary society. Removal of riparian forests aggravates the worrying situation of land use in areas that are dangerous to human habitation, leading to aggradation, erosion, floods and inundations affecting homes of the population that occupies these spaces (SILVA et al., 2016).

In Brazil, the expansion of medium-sized cities has increased significantly since the 80s and 90s, which was a period where most of the urbanization process took place in big metropolitan areas such as São Paulo and Rio de Janeiro. However, currently the rural-urban movement in Brazil is predominantly affecting cities with less than 1 million inhabitants, particularly those located in the midwestern region and the semi-arid areas of the northeastern region (ESPINDOLA et al., 2017).

The lack of adequate urban planning, that takes into consideration the limits of the natural environment, creates a scenario where the land use model is based on the indiscriminate removal of vegetation cover in order to create new spaces for urban expansion. This urbanization dynamic creates large areas of impermeable soil, creating the need to implement a robust drainage system for the surface runoff.

Soil sealing is one of the diffusive forms of soil degradation that occurs after the urbanization process. Despite the installation of innovative pavements, such as permeable ones, in some urban areas in order to mitigate the effects of soil sealing, there is still little research on the effects of permeable pavements on the ground (FINI et al., 2017).

As mentioned above, it is evident that the expansion of urban perimeter has major impacts on the environment, especially on the vegetation cover. According to Arjasakusuma et al. (2018), Normalized difference vegetation index (NDVI) has been widely applied for monitoring vegetation dynamics and its values are known to be profoundly affected by various external factors. The normalized difference vegetation index (NDVI) is an important indicator for evaluating vegetation change, monitoring land surface fluxes or predicting crop models (MILITINO et al., 2017).

Based on the above, this research aimed to analyze the effects of urbanization on the NDVI distribution in the urban area of the municipality of Garanhuns, located in the state of Pernambuco.

\section{METHODOLOGY}

The municipality of Garanhuns (Figure 1) has an area of $458.55 \mathrm{~km}^{2}$ delimited by the following geographical coordinates: $-8^{\circ} 51^{\prime} 37^{\prime \prime} /-^{\circ} 55^{\prime} 40^{\prime \prime}$ and $-36^{\circ} 26^{\prime} 06^{\prime \prime} /-36^{\circ} 30^{\prime} 52^{\prime \prime}$. The area has a high topographic range with an average altitude of $850 \mathrm{~m}$ and maximum of $1050 \mathrm{~m}$ according to the National 
Institute of Spatial Research - INPE (2011). According to Barbosa et al. (2016) the average annual temperature of Garanhuns ranges from 20,1 to $22,0 \stackrel{\circ}{ }$, with a total annual rainfall ranging from 751 to $1000 \mathrm{~mm}$, where the months of July and June are the rainiest and October and November are the driest. Some areas have an altitude ranging from 601 and $800 \mathrm{~m}$ and other areas ranging from 801 and 1000m.
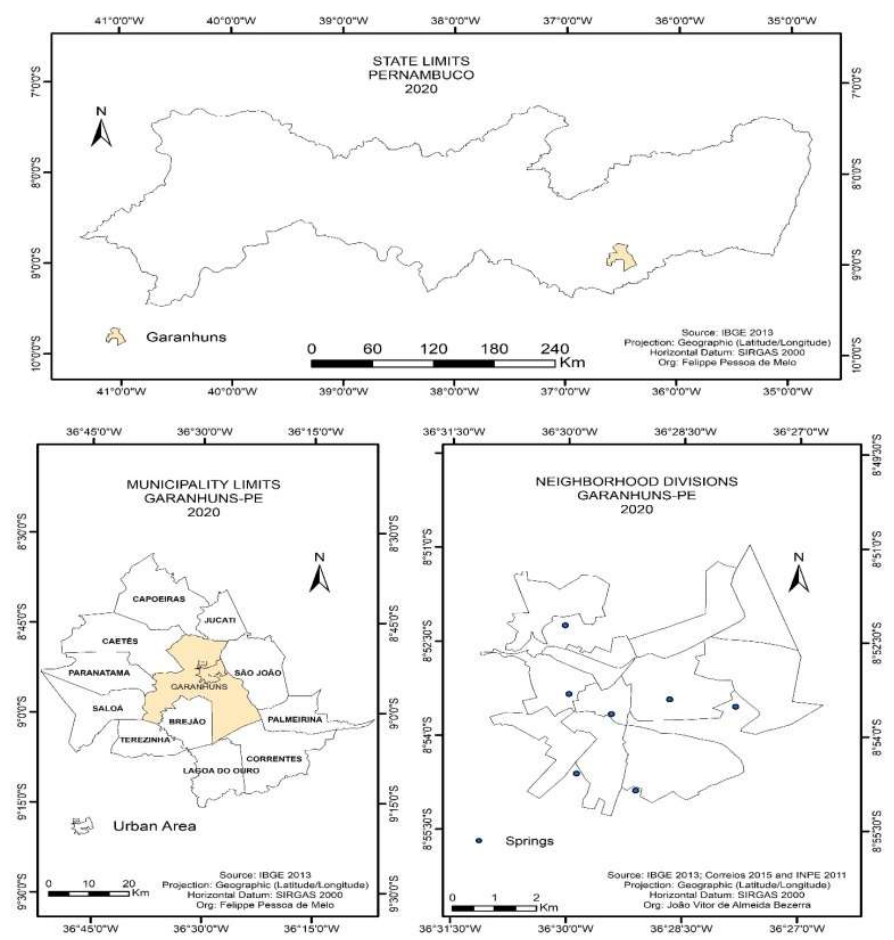

Figure 1: Map of the study area. Source: IBGE (2013); CORREIOS (2015); INPE (2011); GOOGLE EARTH (2016).

Between 1982 and 2004, the urban area of Garanhuns underwent a considerable increase from $76,43 \mathrm{~km}^{2}$ to150,57 $\mathrm{km}^{2}$ due to its role as an important regional city center and eradication policy implemented by the Brazilian Coffee Institute - IBC (MELO, 2013). This eradication caused a great contingent of people to settle in Garanhuns, where those coming from the countryside settled in areas of low commercial value such as natural slopes and the valley bottoms (MELO et al., 2015)

Starting in 1970, the urban area of Garanhuns started to expand with greater intensity, resulting in the emergence and intensification of several socioenvironmental problems such as poor housing conditions in risk areas and the pollution of natural springs that were once used to supply water to the population (SOARES, et al., 2013). The region's geomorphology, high rainfall index and disordered growth aggravate the erosive processes on the landscape contributing to the sedimentation of the natural springs. Because of the lack of basic sanitation, some homes end up disposing their waste directly on the natural slopes or in the inadequate rainwater drains, which ends up contaminating the springs, in other words, in addition to having their flow compromised by sedimentation, the springs are at a risk of being contaminated due to the waste being disposed inadequately.

The urban area of Garanhuns has several natural springs that were severely affected by the municipality's disordered growth, especially the spring named Pau Amarelo. Located at the bottom of the Liberdade Valley in the Heliópolis neighborhood, the spring was responsible for supplying the city with water during the 1930s until the early 1970s. The use of this spring was replaced by dams due to the 
greater amount of water needed to meet the demand, also due to the risk of contamination due to the inadequate disposal of rainwater and waste in the region (SOARES, 2015). Although the municipality is located under the domains of the semiarid climate, it is an exceptional area when compared to the specificities of the semiarid climate due to its mild temperatures and high rainfall indexes.

Among the elements that can influence the conditioning of climatic and meteorological factors, is the effect of continentality, which already has some influence over the rainfall regime of the municipality of Garanhuns, since its location is at a distance of $200 \mathrm{~km}$ from the coast and it can be observed that the altitude exerts great expressiveness in the average temperatures, since in relation to the capital, Garanhuns has higher altitude and milder temperatures, even though it is located in an area of relatively hotter climate (BARBOSA et al., 2016).

Elevation data of the urban area of Garanhuns were collected through the ASTER GDEM v2 program of the National Aeronautics and Space Administration - NASA (2011) with a spatial resolution of 30 meters. The data's projection and datum were altered to Universal Transverse Mercator (UTM) and SIRGAS2000, respectively, using the software Global Mapper 16. Subsequently, the elevation data was exported to the software Surfer 15 where a 3D model and a watershed map of the area were obtained.

In order to evaluate the NDVI on the surroundings of the water streams in the region, the flow vectors from the watershed maps were exported to the software ArcGIS 10.4 where a map was created that establishes an area of 60 meters around said flow vectors. Data related to the red and near-infrared spectral bands were obtained from bands 4 and 5 of the Landsat 8 satellite (years 2015 and 2018) and from bands 3 and 4 of the Landsat 5 satellite (years 1990, 1995, 2000, 2004 and 2009) provided the Earth Explorer website maintained by the United States Geological Survey - USGS which provided atmospherically corrected data.

The aforementioned data was exported to the software ArcGIS 10.4 where an algorithm was elaborated to apply Eq. 1 which according to Tucker (1979), apud Durigon et al. (2014) is used in order to calculate the NDVI.

$$
N D V I=\frac{\rho_{N I R}-\rho_{\text {Red }}}{\rho_{N I R}+\rho_{\text {Red }}}
$$

Where NDVI is the Normalized Difference Vegetation Index; $\boldsymbol{\rho}_{N I R}$ is the near-infrared spectral band and $\rho_{\text {Red }}$ is the red spectral band.

\section{RESULTS AND DISCUSSION}

The 3D model (Figure 2) of the urban area of Garanhuns and its surroundings has a superficial area of $65,37 \mathrm{~km}^{2}$ and the flow vectors that were generated resulted in a total of 25,03 km of length. An area of 60 meters was generated around said flow vectors in the ArcGIS 10.4 software resulting in an area of 3,02 $\mathrm{km}^{2}$. Figure 3 is the result of the application of the NDVI equation on the 3D model above, containing average the NDVI values and standard deviation. 


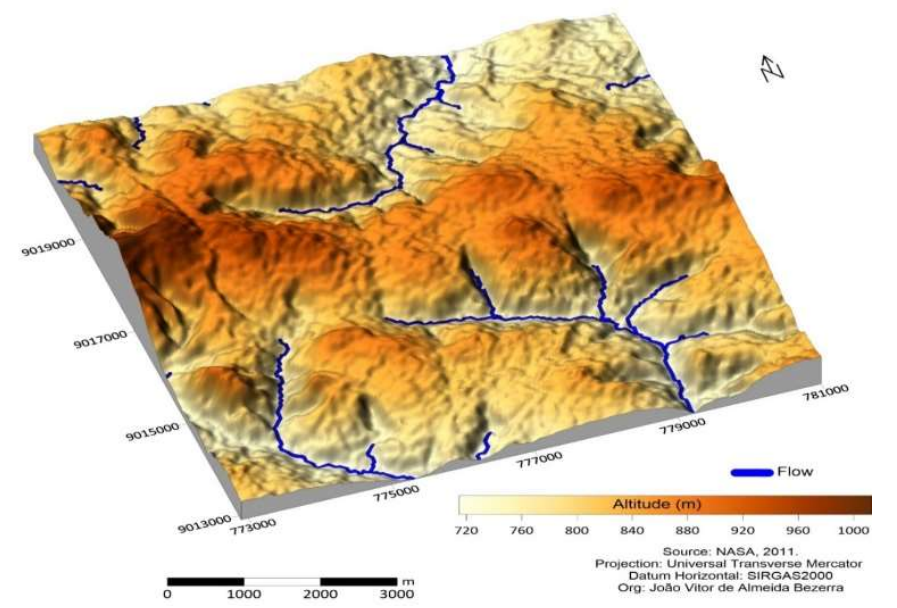

Figure 2: 3D Model of the urban area of Garanhuns-PE and its surroundings. Source: NASA (2011).

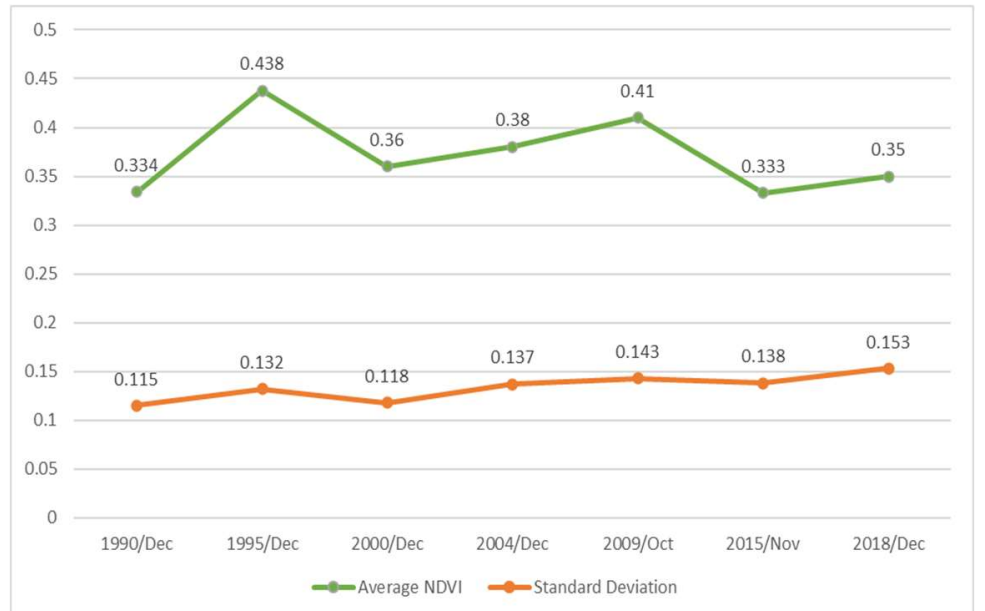

Figure 3: Normalized Difference Vegetation Index (NDVI) of the urban area of Garanhuns-PE and its surroundings. Source: Adapted from Landsat 5 and Landsat 8.

The average NDVI of the urban perimeter and its surroundings do not show a downward trend, which would be expected for a region under a constant expansion of its urban area. However, there is a clear upward trend in the standard deviation of the NDVI, which increased by 33,04\% between 1990 and 2018. According to Deus et al. (2015) the urban area of Garanhuns increased by 20,4\% from 1990 to the year 2000 and $27,8 \%$ from 2000 to 2010. To Soares et al. (2018) the urban growth in Garanhuns was aggravated in the 2000s due to an expressive expansion of the local universities and the increase of the service sector. Melo et al. (2013) point out that the intense urbanization process was responsible for the removal of most of the region's vegetation cover, leaving only remnants in some areas of the municipality of Garanhuns.

The increase of the standard deviation reveals changes in the distribution of the NDVI values in the region, since according to Triola (2019) this statistical parameter is an indication of how much of the data is deviating from the mean value, where the greater the standard deviation is, the higher the data's variability. Thus, these changes can indicate that the average NDVI is constant, but the distribution is not, revealing an increase in both the number of areas with dense vegetation and those with bare or occupied soil.

Figure 4 is the result of the application of the NDVI equation on the 60 meters area surrounding the flow vectors from the watershed map of the study region, containing average values and the standard 
deviation

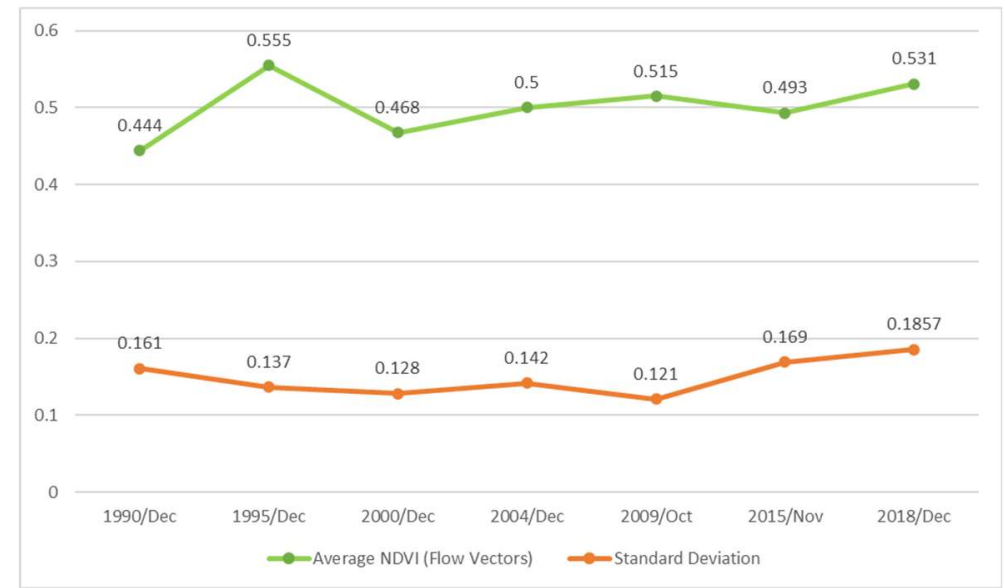

Figure 4: Normalized Difference Vegetation Index (NDVI) of the 60 meters area surrounding the flow vectors of the urban area of Garanhuns-PE and its surroundings. Source: Adapted from Landsat 5 and Landsat 8 and NASA 2011.

Results obtained in the 60 meters area surrounding the flow vectors of the watershed map, showed a higher NDVI average than the region's NDVI average as a whole. This discrepancy is attributed to the greater availability of runoff in these areas. It can be observed that the NDVI average has an upwards trend where it increased by $19.59 \%$ in the period 1990 to year 2018. The standard deviation showed a downward trend in the period of 1990 to year 2009 and an increase of 52.89\% from 2009 to year 2018. This increase coincides with the construction of several large, gated communities surrounding the urban area which initiated an aggressive process of soil sealing in order make these constructions feasible.

The data suggests that the urban development model applied in Garanhuns created imbalances on the natural landscape. The growth of the average NDVI in areas near water streams indicates that there was an improvement in the conditions necessary to allow reproduction of the vegetation cover. However, the standard deviation narrates a scenario where there is an increase in the dispersion of the vegetation, indicating that although the growth of the urban area is creating regions of exposed or occupied soil, it is also creating a scenario of prosperity in regions of natural water flow.

This phenomenon in the NDVI distribution of the urban expansion in Garanhuns can be explained by the dynamics of the rainfall drainage system. Naturally, communities settle near water bodies and streams and due to the absence of an adequate drainage system, the surface runoff ends up being redirected towards natural slopes. This scenario doesn't generate significant changes in the average vegetation, but it does in its distribution, considering that the constant growth of the urban area removes vegetation cover and redirects natural water flow to other areas, creating regions lacking vegetation and others with dense vegetation.

The distribution of soil cover can be observed throughout the several watersheds of the urban area of Garanhuns, such as in the Vila Maria watershed where it is possible to observe that the vegetation is denser along the water stream, creating a contrast between the top (Figures $5 \mathrm{~A}$ and $5 \mathrm{~B}$ ) and the bottom of the valley (Figures $5 \mathrm{C}$ and $5 \mathrm{D}$ ). 


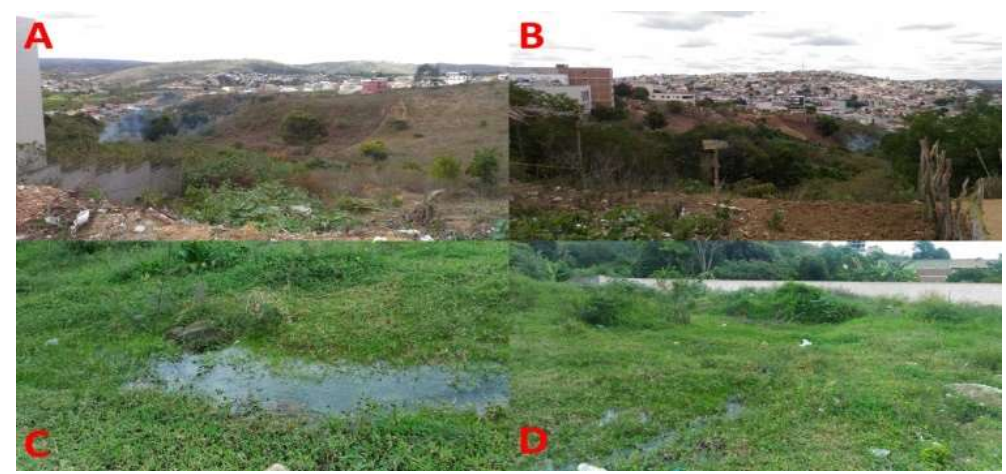

Figure 5: Watershed of the Vila Maria spring

Land occupation on the natural slopes also contributes to the imbalances in the NDVI distribution. Buildings at the top of the Liberdade Valley show the dispersion of the soil cover, where the urban expansion created areas lacking vegetation and others with dense vegetation (Figures 6A and 6B). These disturbances on the landscape are intensified by the inadequate disposal of rainwater (Figure 6C) aggravating the effects of erosive agents on the slope (Figure 6D).

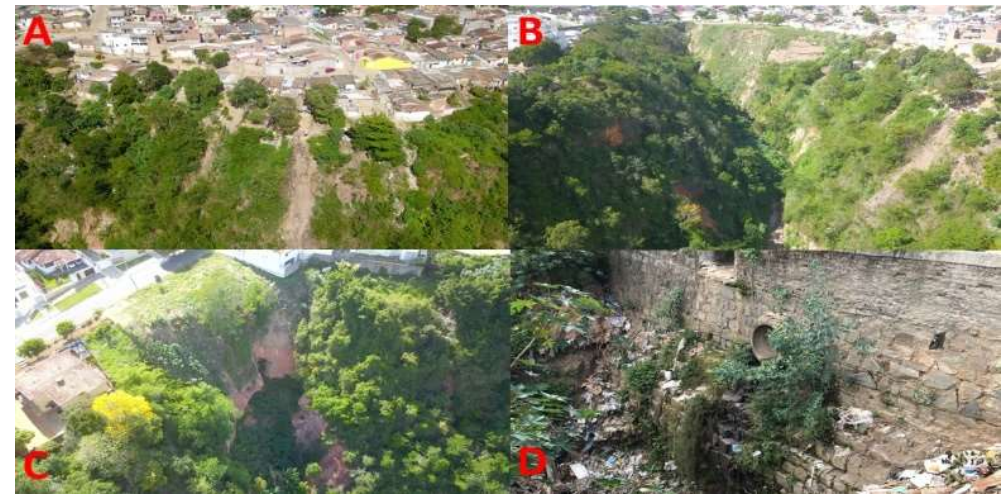

Figure 6: Liberdade Valley in Garanhuns-PE.

Disorderly growth of the urban area around the natural slopes reflects the application of urban planning mode that does not take into consideration the limits of the natural environment. Land occupation is common in risk areas such as the slopes of the Liberdade Valley (Figure 7A) and the application of agricultural techniques (Figure 7B). According to Azambuja et al. (2015) the association of inadequate farming techniques with steep slopes, especially in areas where there is tension between urban and rural space, may have been responsible for the exposed soils on natural slopes, creating instability in the environment of the urban area of Garanhuns.

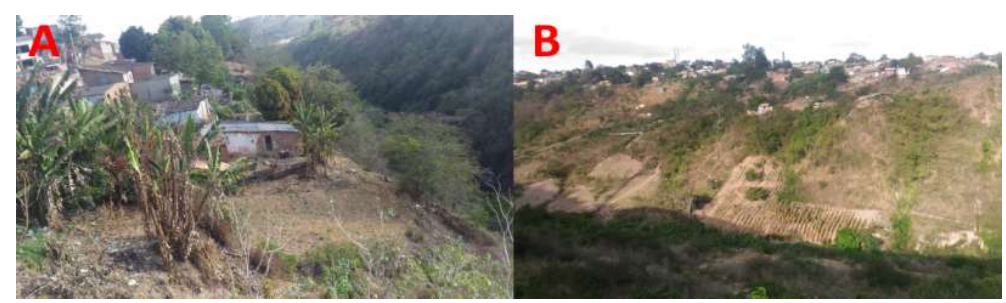

Figure 7: Land occupation in a risk area and farming practices in the Liberdade Valley. Source: Bezerra (2016).

The drainage model of the surface runoff applied in the region consists on the inadequate disposal of water flow directly on the natural slopes, intensifying the effects of erosive agents. Consequences of this 
dynamic can be observed in several watersheds, such as the watershed belonging to the Vila Maria spring where, according to Soares (2015), the inadequate disposal of rainwater on top of the slope, originated a gulley of 300 meters of length with a little over 7 meters of depth. Azambuja et al. (2015) performed a morphodynamical mapping of Garanhuns and they found that the adoption of inadequate construction techniques, poor infrastructure and removal of vegetation cover in areas around springs have increased the erosive processes in a local level. Traces of water erosion show an intensification of surface runoff occurring in different points of the region's watershed. This change in the surface flow dynamics contributes to the behavior of the NDVI distribution, creating areas with intense surface runoff and impermeable areas with little to no runoff. This scenario, product of human actions, can create environmental risks by destabilizing the slopes that are being occupied.

The imbalances in the distribution of the vegetation cover leave certain areas of the slopes unprotected, leaving the soil exposed to intense erosive processes, which can lead to mass movements and weathering of natural springs. The dynamics of the distribution of the local vegetation cover is a symptom of an urban development model that is incompatible with the limits of the local ecosystem. According to Li et al. (2020), climate change and urbanization are the main factors that can alter the processes of vegetation growth in an urban environment.

\section{CONCLUSIONS}

The dynamics of the urban growth in Garanhuns contributed to disturbances on the NDVI distribution, through the creation of several areas lacking vegetation cover and others where the vegetation is dense due to the increase in surface runoff. This dynamic prevented the average NDVI from undergoing abrupt changes, however it's clear that there were changes to the distribution of vegetation cover. Garanhuns' terrain has a high topographic range with several areas of steep slope. Thus, the lack of healthy and uniform vegetation cover can lead to the intensification of erosive processes, which in turn creates areas susceptible to mass movements like landslides. The NDVI pattern in the region can act as an indicator that the development model of the urban area may be disregarding the limits of the landscape.

Finally, it is clear that the urban area expansion occurring in Garanhuns, creates a scenario of environmental risk, since communities are settling in risk areas and due to the lack of an adequate sanitation system, they end up disposing waste and rainwater directly on the natural slopes, which can lead to terrain instabilities.

\section{REFERENCES}

ARJASAKUSUMA, S.; YAMAGUCHI, Y.; NAKAJI, T.; KOSUGI, Y.; SHAMSUDDIN, S.; LION, M.. Assessment of values and trends in coarse spatial resolution NDVI datasets in Southeast Asia landscapes. European Journal of Remote Sensing, v.51, n.1, p.863-877, 2018. DOI:

https://doi.org/10.1080/22797254.2018.1496799

AZAMBUJA, R. N.; CORRÊA, A. C. B.. Geomorfologia e áreas de expansão urbana do município de Garanhuns-PE: uma abordagem espaço-temporal dos eventos morfodinâmicos para o planejamento territorial. Geo UERJ, n.27, p.202-233, 2015. DOI: https://doi.org/10.12957/geouerj.2015.16739

BARBOSA, V. V.; SOUZA, W. M.; GALVÍNCIO, J. D.; COSTA, V. S. O.. Análise da variabilidade climática do município de Garanhuns, Pernambuco - Brasil. Revista Brasileira de Geografia Física, v.9, n.2, p.353-367, 2016. DOI: https://doi.org/10.26848/rbgf.v9.2.p353-367

DURIGON, V. L.; CARVALHO, D. F.; ANTUNES, M. A. H.; 
OLIVEIRA, P. T. S.; FERNANDES, M. M.. NDVI time series for monitoring RUSLE cover management factor in a tropical watershed. International Journal of Remote Sensing, v.35, n.2, p.441-453, 2014. DOI: https://doi.org/10.1080/01431161.2013.871081

MIGUEZ, M. G.; VERÓL, A. P.; RÊGO, A. Q. S. F.; LOURENÇO, I. B.. Urban Agglomeration and Supporting Capacity: the Role of Open Spaces within Urban Drainage Systems as a Structuring Condition for Urban Growth. In: ERGEN, M.. Urban Agglomeration. IntechOpen, p.3-28, 2017. DOI: https://doi.org/10.5772/intechopen.71658

SILVA, A, R. S.; SANTANA, M. D. S.; PASCOAL, R. M.; SILVA, R N. L.. Urbanização desordenada: consequências socioambientais na bacia hidrográfica do Paracuri II, distrito de Icoaraci-PA. Revista IHGP, v.3, n.1, p.31-50, 2016.

ESPINDOLA, G. M.; CARNEIRO, E. L. N. C.; FAÇANHA, A. C.. Four decades of urban sprawl and population growth in Teresina, Brazil. Applied Geography, v.79, p.73-83, 2017. DOI: https://doi.org/10.1016/j.apgeog.2016.12.018

FINI, A.; FRANGI, P.; MORI, J.; DONZELLI, D.; FERRINI, F. Nature based solutions to mitigate soil sealing in urban areas: results from a 4-year study comparing permeable, porous, and impermeable pavements. Environmental Research, v.156, p.443-454, 2017. DOI: https://doi.org/10.1016/i.envres.2017.03.032

INPE. Instituto Nacional de Pesquisas Espaciais. Projeto Topodata. 2016.

IBGE. Instituto Brasileiro de Geografia e Estatística. Malhas Digitais. 2016.

MELO, F. P.. Modelo de uso e ocupação da paisagem no município de Garanhuns - PE. Reget, v.10, n.10, p.21982207, 2013. DOI: https://doi.org/10.5902/223611707857

MELO, F. P.; SOUZA, R. M.. Mapeamento geomorfológico da fragilidade ambiental do sítio urbano de Garanhuns - PE. Nativa. Sinop, v.3, n.4, 2015. DOI: https://doi.org/10.31413/nativa.v3i4.2191
MELO, F. P.; ALMEIDA, J. P.. Crescimento urbano desordenado e seus reflexos nas encostas dos vales de Garanhuns-PE. ANAP Brasil, v.6, n.7, p.40-65, 2013. DOI http://dx.doi.org/10.17271/19843240672013422

MILITINO, A. F.; UGARTE, M. D.; PÉREZ-GOYA, U.. Stochastic spatio-temporal models for analysing NDVI distribution of GIMMS NDVI3g images. Remote Sensing, v.9, n.76, 2017. DOI: https://doi.org/10.3390/rs9010076

SOARES, A. B.; SANTOS, C. C.; CAVALCANTI, M. A. Problemática socioambiental urbana na nascente Pau Amarelo em Garanhuns - PE. Revista Brasileira de Geografia Física, v.6, n.5, 2013. DOI: https://doi.org/10.26848/rbgf.v6.5.p1141-1157

SOARES, A. B.. Análise da problemática socioambiental das nascentes urbanas no município de Garanhuns - PE. Dissertação (Mestrado em Geografia) - Universidade Federal do Rio Grande do Norte, Natal, 2015.

NASA. National Aeronautics And Space Administration. The Global Data Explorer, 2016

DEUS, R. A. S. G.; RAMOS, R. P. S.; COSTA, S. O. S.; GOMES, D. D. M.. Análise multitemporal da expansão urbana do município de Garanhuns - PE, através do sensoriamento remoto. Reget, v.19, n.2, p.1535-1544, 2015. DOI: https://doi.org/105902/2236117015541

SOARES, A. B.; TROLEIS, A. L.. A expansão urbana de Garanhuns-PE entre 1811 e 2016 e suas implicações socioambientais. Revista Movimentos Sociais e Dinâmicas Espaciais, v.7, n.1, p.185-209, 2018.

TRIOLA, M. F.. Essentials of Statistics. 6 ed. New York: Pearson, 2019

LI, D.; WU, S.; LIANG, Z.; LI, S.. The impacts of urbanization and climate change on urban vegetation dynamics in China. Urban Forestry \& Urban Greening, v.54, 2020. DOI: https://doi.org/10.1016/j.ufug.2020.126764

A CBPC - Companhia Brasileira de Produção Científica (CNPJ: 11.221.422/0001-03) detém os direitos materiais desta publicação. Os direitos referem-se à publicação do trabalho em qualquer parte do mundo, incluindo os direitos às renovações, expansões e disseminações da contribuição, bem como outros direitos subsidiários. Todos os trabalhos publicados eletronicamente poderão posteriormente ser publicados em coletâneas impressas sob coordenação da Sustenere Publishing, da Companhia Brasileira de Produção Científica e seus parceiros autorizados. Os (as) autores (as) preservam os direitos autorais, mas não têm permissão para a publicação da contribuição em outro meio, impresso ou digital, em português ou em tradução. 